\title{
ÎNVĂŢĂMÂNTUL MUZICAL BISERICESC ALBAIULIAN. MISIUNE, TRADIȚIE ŞI ACTUALITATE
}

Domin Adam*

\begin{abstract}
Alba Iulia, the old Romanian and orthodox center of culture and spirituality, was remarked from antiquity. Here, the dacians built an important military center; the romans, the austrians and the hungarians did the same. As a political center, the music was never missing from the citadel. During the Renaissance, musicians from Italy and France were brought into the citadel. The monasteries and the hermitages around the citadel, were supporters of plastical orthodox music culture. The mitropoly of Alba Iulia supported the romanian spirituality through printing worship and musical books. Due to the foreign occupation, the romanians did not have musical schools until the XIXth century. The school during that period took place in churches, and there the pupils were thought to write, to read and to $\operatorname{sing}^{1}$.
\end{abstract}

Key words: music, church, singing, tradition, culture, spirituality, orthodoxy.

\section{Introducere}

Cântarea religioasă în Transilvania s-a învăţat în biserică şi şcoli după vechea metodă orală perpetuată din generaţie în generaţie. Ea a favorizat păstrarea cântării româneşti dinainte de 1700 ,

\footnotetext{
"PhD, Rev Professor, "1 Decembrie 1918” University , Faculty of Orthodox Theology, Alba Iulia, Romania.

${ }^{1}$ Octavian Lazăr Cosma, Hronicul muzicii româneşti, Bucureşti, Editura Muzicală, 1975, vol. III, p. 172.
} 
„îngăduind în acelaşi timp o mare varietate de la o localitate la alta, se dădea o singură stihiră ca model, ceea ce lăsa frâu liber aplicării diferitelor texte pe melodia glasului respectiv"2. Păstrarea cântării tradiționale peste veacuri a fost posibilă datorită izolării unor sate, „ceea ce a împiedicat îndepărtarea de curentul grecesc-oriental a cântării din Transilvania"

Cântarea omofonă (la unison) sau comună s-a dovedit în toate vremurile şi în toate timpurile a fi un mijloc potrivit a aduce pe credincioşi la Sfintele slujbe; ea a cunoscut nebănuite culmi în trecut, nefiind nicidecum o inovație, din contră prin felul ei atrage pe credincioşi şi creează cadrul potrivit pentru catehizare ${ }^{4}$. Această cântare a fost sprijinită, ca şi cea polifonică, de unii ierarhi de seamă de mai târziu, ca vrednicul de amintire Patriarhul Iustinian ${ }^{5}$, urmărindu-se unitatea cultică ${ }^{6}$ între cele trei provincii româneşti şi între celelalte Biserici Ortodoxe.

\section{Cuprins}

Învățământul muzical bisericesc în Ardeal şi în special la Alba Iulia, căci era capitala principatului, era pur practic, tradițional. Cântăreți bisericeşti deveneau, de obicei, oamenii simpli cu voce aleasă şi cu auz muzical bun, aceiaşi oameni-cum spunea Gheorghe Şoima-care: „,̂n afară de biserică, cântau bucuroşi un întreg repertoriu de cântece populare. Când, în mod inconşstient, aceşti cântăreți împleteau motive bisericeşti cu motive populare, nu era cine să-i corecteze. Dar, fără îndoială, că nu muzica de joc şi nici cea lumească va fi fost aceea care a influențat muzica bisericească, ci mai degrabă melodiile doinelor noastre ... Dacă însă, cu alte prilejuri, ne place să ne luăm la întrecere în a sublinia cât mai mult

\footnotetext{
${ }^{2}$ Ibidem.

${ }^{3}$ Gh. Şoima, Muzica bisericească şi laică în Institutul Teologic din Sibiu, în: Rev. Mitropolia Ardealului, nr.11-12, 1961, p. 798.

${ }^{4}$ Nicu Moldoveanu, Muzica bisericească, B.O.R., nr. 6, 1973, p. 650.

${ }^{5}$ Nicolae Necula, Particularități ale ritului liturgic ortodox rus față de celelalte Biserici Ortodoxe autocefale, M.A., nr. 7-8, 1965, p. 70.

${ }^{6}$ Gheorghe Şoima, Funcțiunile muzicii liturgice, Sibiu., 1945, pp. 85-86.
} 
frumusețea doinelor..., de ce când vine vorba de influența pe care au putut-o exercita, în Ardeal, asupra muzicii bisericeşti ... ne speriem atât de tare şi această influență ni se pare atât de nefastă?"7.

În Transilvania unele melodii bisericești, de exemplu pricesnele, sunt aproape identice cu doinele sau cu cântecul popular, precum şi cântece populare, care dau impresia ,că asculţi o veritabilă podobie"». În Ardeal, identitatea legii românești şi a credinței se extinde şi în muzică ${ }^{9}$. Aici, unele cântări bisericeşti şi muzica populară românească înseamnă aproape acelaşi lucru, „Cântarea populară a românizat cântarea bisericească, iar aceasta a imbisericit parțial muzica populară ${ }^{\prime 10}$. Despre influența stilului popular în cântarea bisericască din Ardeal, vorbeşte şi Nicolae Lungu ${ }^{11}$, afirmând că ea se simte în special în creația corală liturgică a unor compozitori ca: G. Dima, I. Vidu, T. Popovici etc.

$\mathrm{O}$ vatră mănăstirească în care a existat o şcoală de pregătire pentru preoți (de fapt o şcoală de cântăreți bisericeşti) a fost schitul Afteia, din Plăişorul Cioarei. Aici, în secolul al XVIII-lea, au avut loc fapte însemnate pentru cultura şi ,legea românească”, prin oferirea învăţăturii gratuite pentru copii din satele dimprejur şi a cunoştințelor necesare candidaților la preoție, precum şi unele meşteşuguri dintre care amintim pictarea icoanelor pe sticlă ${ }^{12}$.

Şcolile de cântare bisericească au fost foarte importante, însă nu s-a făcut nimic pentru sprijinirea lor şi nici a absolvenților lor, deşi ei au fost cei care au luminat, alături de preoți, uneori chiar şi singuri, poporul român din Ardeal.

\footnotetext{
${ }^{7}$ Ibidem, p. 86.

${ }^{8}$ Ibidem, p. 87.

${ }^{9}$ Ibidem.

${ }^{10}$ Nicolae Lungu, Tehnica recitativului liturgic. Organizarea corului bisericesc, S.T. nr. 3-4, 1949, p. 247.

${ }^{11}$ Dragosin Oană, Sfântul Sofronie şi mănăstirea lui din Plăişorul Ciorii, Alba Iulia, 1995, p. 14; vezi şi Silviu Dragomir, Istoria dezrobirii religioase a românilor din Ardeal în secolul XVIII, vol. II, Sibiu, 1930, p. 153.

${ }^{12}$ Şefan Bârsăescu, Pagini nescrise din istoria culturii româneşti (sec X-XVI), Bucureşti, 1971, p.139.
} 
Că şcolile de cântare bisericească şi învățământul muzical bisericesc aveau un important rol ne spun şi actele din primii ani ai ocupației maghiare în: Acta scriptorum rerum Hungaricarum, I, 326 - de care vorbeşte Ştefan Bârsănescu. În acest act este menționat un „magister Nikolaus de Moldova" care în 1425 participă la Feldioara (Transilvania) la examinarea unui tânăr pentru un post de cantor ${ }^{13}$. Iată cât de importantă era munca unui cantor, încât pentru examinarea lui vine un dascăl renumit dintr-o şcoală moldoveană (poate Putna). Contactele dintre românii din principate a făcut posibilă şi circulația cărților, fie de cult, fie de cântece bisericeşti.

Istoricul Flavio Biondo, la 1453, se adresează regelui Alfons al Siciliei, în legătură cu organizarea unei cruciade împotriva turcilor, prilej cu care îi vorbeşte despre românii din Banat şi despre faptele lor (textul e în limba latină). La mai bine de un secol după această informație a lui Flavio, în Transilvania apare o carte de cântece românească, scrisă cu litere latine şi cu ortografie maghiară. Un fragment din această tipăritură (numită după cel ce a descoperit-o Fragmentul Teodorescu) - a fost publicat în $1911^{14}$. Locul unde s-a tipărit cartea nu se cunoaşte exact (Alba Iulia, Oradea sau Cluj), se ştie că este o carte calvină, tradusă din maghiară în română, cu un scop bine fixat şi cu siguranță că era tot pentru bănățeni şi hunedoreni unde calvinismul prinsese rădăcini adânci. Anul apariției este 1560-1570, iar în anii care au urmat au apărut alte copii ${ }^{15}$. Cartea ii este atribuită episcopului calvin de origine română Pavel Tordaşi ${ }^{16}$, iar alfabetul folosit era cel latin ${ }^{17}$.

${ }^{13}$ H. Sztripsaky şi G. Alexics, Szegedi Gergely enekeskonyve XVI szazadbeli roman forditasban, Budapesta, 1911; publicat de Alexevici, Revista de istorie şi filologie, Bucureşti, 1913, pp. 279-283 (cuprinde Tatăl nostru şi poezii populare).

${ }^{14}$ Ion Gheție, Inceputurile scrisului în limba română, Bucureşti, 1974, pp. 21 24.

${ }^{15}$ Ibidem, p. 153.

${ }^{16}$ Adrian Andrei Rusu, Ctitori şi biserici din Țra Hațegului până la 1700 , SatuMare, 1997, p. 88.

${ }^{17}$ Sebastian Barbu-Bucur, Cultura muzicală de tradiție bizantină pe teritoriul României în secolul XVIII şi începutul secolului XIX şi aportul original al 
Ca răspuns la această carte, probabil, în secolul XVII, Mitropolitul Simion Ştefan de la Alba Iulia a scris o alta, intitulată: „Cântările noastre bisericeşti deosebite de cele latineşti”, tipărită la Alba Iulia ${ }^{18}$ (până astăzi această carte nu a fost găsită). Nu se putea trece cu vederea peste comoara de cântece ale Bisericii noastre care atunci când sunt interpretate cu adevărată pătrundere, "ele exercită $o$ influență poate mai eficace decât cea mai măiestrită cuvântare, compusă după toate regulile oratoriei”" ${ }^{\prime 19}$.

Umanistul $^{20}$ Nicolae Olahus, de origine română, care era înrudit cu neamul Corvinilor, a fost cel care a organizat în Ungaria învățământul de toate gradele, inclusiv superior ${ }^{21}$. El a dispus ca fiecare paroh din Ungaria să angajeze câte un învăţător care să-i învețe pe copii scrisul, cititul si cântările bisericeşti ${ }^{22}$. El ştia că aşa se făcea şi în țările Române şi a văzut rolul şi eficacitatea acestor trei elemente în propăşirea neamului, culturii şi a credinței, chiar dacă se făceau într-un mod precar la început. Ca nepot al lui Matei Corvin şi cu concursul acestuia, ca o conlucrare, Nicolae Olahus ${ }^{23}$ pune bazele învățământului maghiar. Matei Corvin fondează Universitatea din

culturii autohtone, Bucureşti, Editura Muzicală, 1989, p. 39; apud Romeo Ghircoiaşiu, Contribuții la istoria muzicii româneşti, Bucureşti, 1963, vol. I, p. 98.

${ }^{18}$ Eusebiu R. Roșca, Monografia Institutului Seminarial Teologic-Pedagogic “Andreian" al Arhidiecezei Greco-Ortodoxe Române din Transilvania, Sibiu, Tipografia Arhidiecezană, 1911, p. 117.

${ }^{19}$ Ibidem.

${ }^{20}$ Umanismul $=$ aceast ${ }^{\wedge}$ denumire s-a dat pentru a defini conținutul esențial al culturii din epoca Renaşterii. Este o concepție filosofică laică antropocentristă ce priveşte viața şi întreaga existență prin prisma intereselor fireşti ale omului. Vezi I.S. Firu, Corneliu Albu, op.cit., p. 53.

${ }^{21}$ I.S. Firu, Corneliu Albu, Umanistul Nicolae Olahus (1493-1568), Bucureşti, Editura Ştiințifică, 1968, p. 65.

${ }^{22}$ Ibidem p. 47.

${ }^{23}$ Ibidem, p. 22 
Budapesta şi vestita bibliotecă „Corviniană,"24, deci un român descendent din neamul Basarabilor ${ }^{25}$.

Prin apariția Reformei influența catolică încetează, locul acesteia luându-l calvinismul şi luteranismul care până în 1699 a încercat să atragă populația românească din Ardeal la religia lor. În 1699 Transilvania intră în stăpânirea austriacă, iar catolicismul este repus din nou în drepturi, reuşind să dezbine Biserica Ortodoxă din Ardeal.

Mitropolia Transilvaniei, cu sediul la Alba Iulia, avea în secolele XVI-XVII, 16 episcopii sufragane, iar ca centru politic şi religios este imposibil să nu fi avut o şcoală în care să fi fost pregătiţi cel puțin preoții şi cântăreții, şcoală a cărei existență a fost legată de mitropolie. Cert este faptul că principii Transilvaniei, aşa cum au luptat împotriva Bisericii, tot aşa au luptat şi împotriva şcolii de aici ca şi împotriva legăturilor cu fraţii de peste munți. $\mathrm{O}$ mărturie grăitoare este ordinul dat de principele Sigismund al Transilvaniei, la 10 septembrie 1600, prin care: ,era ucis orice român sau sârb ce ținea de Voievod"'- de Mihai Viteazul - ${ }^{26}$, nici popă românesc să nu poată intra vreodată din cele două țări româneşti, iar călugării cu totul să fie proscrişi din toată țara. De se va afla vreunul că a intrat ori va intra, contra edictului țării, pe acela să-l prindă şi să-l despoaie oriiunde"27.

Şcolile de pe lângă biserici şi mănăstiri şi de pe lângă mitropolie, iar mai târziu şcolile confesionale aveau între disciplinele de studiu muzica bisericească. Aceste şcoli susținute de biserică, sunt ca o „fiică” a acesteia ${ }^{28}$, e firesc ca întreaga muncă ce se desfăşoară în ea să poarte mai înainte de toate un timbru religios, ,era un mijloc de promovare a educației religioase" ${ }^{\text {"29 }}$.

${ }^{24}$ Ion Clopoțel, Dinastia română a Corvinilor (500 de ani de la cruciadele lui Iancu Huniade), Lugoj, Editura "Societatea de mâine", 1942, p. 29.

${ }^{25}$ Ibidem, p. 31.

${ }^{26}$ Nicolae Iorga, Istoria românilor din Ardeal şi Ungaria, Bucureşti, 1915, vol.

I, p. 14.

${ }^{27}$ Ibidem, p. 15.

${ }^{28}$ Onisifor Ghibu, Anuarul Pedagogic, București, 1913, p. 184.

${ }^{29}$ Ibidem. 
Începuturile învăţământului muzical religios în Alba Iulia şi în împrejurimile acestuia sunt strâns legate de activitatea mănăstirilor şi bisericilor ortodoxe. Ca în întreaga Transilvanie forma de dezvoltare a şcolilor româneşti a fost mult timp frământată de dubla asuprire politică şi religioasă la care a fost supusă populația românească.

Creştinismul şi-a creat propria muzică de cult căreia i-a dat un puternic accent tradițional, preluând acest fond al tradiției muzicale populare în cântările bisericii. Aşa ne explicăm înrudirea dintre vechea muzică română cultică şi creația folclorică românească. Exemplul cel mai edificator constituindu-1 colindele ${ }^{30}$, gen muzical de bază în ciclul sărbătorilor de iarnă şi care îşi are o obârşie mult mai îndepărtată în istorie. Aceste colinde sunt foarte bogate din punct de vedere al conținutului religios, al ritmului şi melodiei în toate provinciile româneşti, dar îndeosebi în Ardeal.

Dezvoltarea feudalismului a impus o tot mai mare răspândire a scrisului şi a muzicii care erau nelipsite de la curţile medievale domneşti, voievodale şi de la cele episcopale. La curtea princiară din Alba Iulia, în perioada Renaşterii, au activat împreună cu muzicieni autohtoni şi creatori şi interpreți italieni, flamanzi, spanioli, de renume european ${ }^{31}$. De la cărțile de ritual imprimate peste hotare s-a ajuns la tipăriturile locale de muzică polifonică religioasă ale lui Johanes Honterus şi Valentinus Wagnerus Coronensis la Braşov ${ }^{32}$.

Sub influența Renaşterii, învățământul muzical dă la iveală şcoli de tip renascentist. O primă şcoală este Colegiul Bethlenian din Alba Iulia. „Două căi ar sta deschise românilor pentru înlăturarea lipsurilor: biserica şi teatrul. Cum ultimul lipseşte, ar rămâne ca

\footnotetext{
${ }^{30}$ Colindele diferă de la o regiune la alta, prin structura şi ritmul lor. Melodia lor este construită fie pe baza unui ritm neschimbat, fie pe felurite combinații ritmice. Vezi D. Bughici, D. Gheciu, Formele şi genurile muzicale, Bucureşti, Editura Muzicală, 1962, p. 157.

${ }^{31}$ Viorel Cosma, Două milenii de muzică pe pământul României, Bucureşti, 1977, p. 31.

${ }^{32}$ Ibidem.
} 
unică soluție cultivarea cântărilor noastre bisericeşti” ${ }^{33}$, făcând din ele adevărate bijuterii.

Prin şcoliile înființate, prin tipografii, biblioteci-se vede setea de cultură a poporului. Oamenii înstăriţi angajau câte un preceptor pentru copii lor ca să-i învețe carte. Românii însă nu aveau voie să învețe carte la început, abia prin legile din anii 1624 şi 1635 li se permitea iobagilor români să învețe în şcoli confesionale fără să scape de iobăgie şi de înrolare la oaste, „mai învățau carte cei ce voiau să ajungă popi, dascăli şi dieci - ințelegându-se clasa cărturarilor numiți în țările vecine logofeți (cancelari), plătind 300 florini (în timpul lui Mihai Apaffi)" 34 .

Şcolile de pe lângă biserici unde se învăţa scrisul şi cititul erau necesare pentru cancelariile centrelor politice. Începând cu secolul al XII-lea, vor fi întocmite diplome şi legi scrise de dieci ştiutori de carte, dascăli care adesea ocupau funcția de cancelari sau de slujbaşi săteşti. În acest sens un rol important 1 -au jucat şcolile înființate de ordinul benedictinilor şi dominicanilor, începând cu secolul XII la Cluj-Mănăştur, Alba Iulia, Vințul de Jos etc. Mai târziu (secolul XIV) aceste ordine se ocupă şi de educarea fetelor înființând şcoli speciale pentru acestea, şcoli ca cea de la Alba Iulia şi Cluj. Trebuie ştiut că până acum nu se făcuse pentru fete nimic. Partea bărbătească era sortită studiului şi armelor, pe măsura putinței lor, iar fetele erau sortite măritişului, familiei, creşterii copiilor. Asemenea şcoli au existat şi pe lângă alte biserici şi mănăstiri chiar dacă nu erau separate, ci mixte.

Denumirea de dascăl e identică cu cea de pevet, cântăreț, cantor, protopsalt, domestic mai târziu lampadari, dieci şi învățători. Toate aceste denumiri indică una şi aceeaşi persoană, pe cântărețul de strană şi pe îndrumătorul învățăceilor în ale scrisului, cititului şi ale cântărilor patriotice sau naţionale, populare, de

\footnotetext{
${ }^{33}$ George Em. Marina, Iosif Hojos, Călina Mare, Constantin Rusu, Ideologia generației române de la 1848 din Transilvania, Bucureşti, Editura Politică, 1968, p. 128; vezi şi N. Tincu - Velea - articol în Foaie pentru minte, IX (1846), nr. 44, p. 348.

${ }^{34}$ George Barițiu, Istoria Transilvaniei, Sibiu, 1889, vol. I, p. 119.
} 
strană sau bisericeşti. Aceştia erau recrutaţi dintre cursanţii şi absolvenții şcolilor de pe lângă biserici.

De la sfârşitul sec. XIV se păstrează informația cu privire la folosirea limbii române în biserică şi şcolile din Transilvania. Documentul concludent este de la 1374, când sub presiunea regalităţii maghiare şi a papalității o mică parte a românilor a trecut la catolicism pentru a obține anumite favoruri. Li s-a permis să folosească limba română în biserici, numindu-li-se chiar şi un episcop român catolic pentru că nu erau mulțumiți cu episcopii unguri $^{35}$.

Melodiile bisericeşti: liturghia, glasurile, erau învăţate în mare parte pe dinafară. Această formă de învățare era transmisă din generație în generaţie. Şcolile maghiare din mediul urban erau mai bine organizate față de cele rurale pentru că aveau programe bine rânduite şi dascăli mai buni. Ele erau conduse de un „magister" numit şi „,rector scholae”, ,magister scholae”, iar documentele vremii pomenesc de circa 20 de şcoli orăşăneşti ${ }^{36}$ înfiinţate între 1352-1526 în Transilvania. Cele din mediul rural stăteau mai bine din punct de vedere economic şi au fost înființate înaintea celor de la oraş ${ }^{37}$. În aceste şcoli instruirea era făcută de preoții parohi - iar mai târziu, în şcolile mai mari- de un „magister” care putea să fie şi un laic ales de locuitori, dar aprobat de paroh. În şcolile parohiale elevii studiau religia, muzica bisericească, rânduielile slujbelor scrisul şi cititul ${ }^{38}$.

În secolul XIV aceste şcoli se dezvoltă sub toate aspectele, calitativ şi ca număr. Ulterior apare ciclul al doilea „qvadrivium” unde se studia: aritmetica, muzica, geometria şi astronomia. $\mathrm{Cu}$ toată îmbunătățirea calității învățământului erau foarte mulţi neştiutori de carte sau cu cunoştințe puține, din cauza sărăciei şi a

${ }^{35}$ Ibidem.

${ }^{36}$ I. Kovàcs, Şcolile orăşeneşti maghiare, în: Istoria Învățământului românesc, vol. I, Bucureşti, 1992, p. 95.

${ }^{37}$ Ibidem, p. 96.

${ }^{38}$ Ibidem. 
neputinței de a-şi plăti taxa şcolară. Erau foarte mulți preoți care ştiau numai să citească, nu să şi scrie ${ }^{39}$.

Pe la sfârşitul sec. al XIV-lea şcolile săteşti încep să se laicizeze. Sătenii îşi aduc dascăli bine pregătiți, cu studii în centre mari europene, pe care îi plătesc bine. Aceştia aveau şi câte un ajutor (din cauza creşterii numărului elevilor) numit în limba latină locatus, socius, praeceptor, datorită faptului că mulți dascăli mai aveau şi funcţia de notar îndeplinind uneori şi alte misiuni în folosul comunității. Dascălul şi ajutorul lui erau singurele persoane din sat care cunoşteau scrisul, cititul şi cântarea ${ }^{40}$.

Un regulament din 1447 ne spune că învăţătorii erau subordonați preotului, fiind obligați să-l ajute pe preot la lucrările câmpului şi să îndeplinească funcția de curier ${ }^{41}$.

După înfrângerea răscoalei lui Gheorghe Doja, satele nu mai vor să primească dascălii trimişi de episcopul catolic ci şi-i aleg ei. La oraşe, unde învățământul era mai bine organizat, se duce o luptă aprigă între conducătorii oraşelor şi Biserică, revendicânduşi şi unii şi alții conducerea şcolilor. La oraş şcolile evoluează ca cele din Apus, sub forma unor şcoli triviale şi cvadriviale, adică ciclul întâi şi ciclul doi.

Acțiunea de câştigare a românilor din Ardeal la reformă a fost conjugată cu traducerea cărților religioase în limba română, lucru foarte important pentru că limba română devine o limbă scrisă (tipăriturile). La încercările de convertire la reformă episcopii ortodocşi s-au preocupat mai întâi de tipărirea de cărți în limba slavonă, apoi în limba română, punându-se bazele şcolii româneşti de traducere şi tipărire de cărți.

Când cele trei Principate sunt unificate la 1600, se revine la tradiția slavonă pentru a apăra credința de influențele reformei. Cărțile ce s-au tipărit la Alba Iulia erau în special cele de cult, de uz liturgic şi muzical.

\footnotetext{
${ }^{39}$ Ibidem.

${ }^{40}$ C. Gällner, Şcolile capitulare orăşeneşti germane, în Ist. Înv. din Rom., op. cit., p. 97.

${ }^{41}$ Ibidem.
} 
Cântarea bisericească era învățată pe cale orală şi a păstrat o reală asemănare cu glasurile bisericeşti psaltice de peste munți. Deşi libera circulație în celelalte provincii a fost uneori oprită, ea nu a putut fi decât de scurtă durată. Pelerinajele la mănăstiri sunt un exemplu în acest sens. Aşa cum se fac astăzi pelerinaje la unele mănăstiri şi biserici tot aşa se făceau şi în trecut, luând legături românii între ei şi învățând cântările bisericii, căci numai cântecul, credința şi limba i-a ajutat să treacă peste negura vremurilor.

La Alba Iulia, la Colegiul Reformat Bethlenian înființat în 1622, muzicii i se acordă un loc de seamă. Aici învățătorul era obligat să învețe toate cântările necesare în duminici. În Biserica Ortodoxă din Ardeal se întâmpla acelaşi lucru.

Mănăstirea Lupşa avea o şcoală pe care o întâlnim menționată până în 1848, sub numele de ,şcoala de la mănăstire”. În legătura cu importanța şcolii de la mănăstire istoricul Augustin Bunea spunea în 1902: „din timpurile cele mai vechi la această mănăstire se ținea şcoală pentru cantori şi preoți până la finele veacului al XVIII-lea.

O şcoală a existat şi la Mănăstirea Râmeț. Acest lucru rezultă dintr-o cronică păstrată de la 8 august 1821 , când sătenii spuneau: „Noi Râmeții şi Ponorii de cându-s aceste două sate, noi acolo (la mănăstire) ne-am pomenit a avea o şcoală şi acolo avem şi acum casă de şcoală şi dascăli de învăț, şi dacă ni se ia aceea noi rămânem fără învățăturăa",

O altă mănăstire importantă din punct de vedere cultural şi spiritual este mănăstirea Măgina de lângă Aiud. Această mănăstire a fost înființată în 1611 şi a adăpostit pe lângă ea, de la început, o şcoală ${ }^{43}$. Şcoala de la mănăstirea Măgina este cea mai veche şcoală românească din județul Alba, despre care există dovezi ${ }^{44}$, care-şi

\footnotetext{
${ }^{42}$ Ştefan Meteş, op.cit., p. 39; Stanca Sebastian, Mănăstirea de la Râpa Râmețului, în Calendarul Eparhiei Române Ortodoxe a Clujului, Cluj, 1936, p. 18.

${ }^{43}$ Nicolae Albu, Şcoala de pe lângă Mănăstirea Măgina, în Apulum XIV, p.476.

${ }^{44}$ Şematismul de la Blaj, pe anul 1900, Blaj, Tip. Seminarului Arhidiecezan, 1900 p. 124.
} 
adăpostea elevii în chiliile mănăstirii. Că şcoala de la Măgina a fost tot timpul o instituție de cultură aleasă rezultă din faptul că ea e fost cuprinsă în decretele imperiale ale lui Iosif al II-lea din 1875, fiind socotită între celelalte şcoli ,triviale" din Transilvania ${ }^{45}$. Pentru meritele deosebite în propagarea culturii, decretele împărăteşti o numără printre mănăstirile care poartă „grija sufletelor şi invățarea pruncilor" ${ }^{, 46}$. Fiindcă avea dascăli buni la ea alergau tinerii din toate împrejurimile, ,faima ei ajunsese până in Slovacia" 47 . Pe lângă scris, citit, socotit şi catehism mai învățau rânduielile slujbelor, cântările liturghiei şi glasurile. Cei care terminau cursurile acestei şcoli deveneau dascăli şi dieci (cine ştie poate şi preoți).

În multe sate româneşti scrisul şi cititul constituia o problemă din cauza conducerii maghiare şi a magnaților unguri care îi obligau pe români să muncească pentru ei toată săptămâna, dându-le liber doar duminica, pentru reculegere şi şcoală. La început, dascăl era însuşi preotul; de altfel locul şcolii ca şi natura învățăturilor care le preda îl indicau pe el a fi cel mai potrivit. Şcoala se făcea în tinda bisericii, trecerea de la liturghie la şcoală era aproape pe nesimțite; sau chiar Liturghia în sine era o oră de curs prin simbolistica, prin textele ei, prin citirile biblice şi prin cântări. Se citea Cazania, se rosteau rugăciunile şi se învăţau cântările bisericii, se repetau până se învățau. Vara se făcea şcoala afară, în curtea bisericii, copii învățau să scrie pe nisip, iarna pe zăpadă, dar de multe ori se renunța la scris, învățându-l doar cei ce voiau să devină preoți sau dieci, în rest se mulțumeau cu învățarea cântărilor şi rugăciunilor necesare în cadrul cultului. Scopul formelor de învățământ românesc de la începutul secolului XVII

\footnotetext{
${ }^{45}$ Circulara episcopului Ioan Bob în Protocolul episcopal pe 1785, Arhivele Statului, Blaj, vezi Nicolae Albu, p. 465.

${ }^{46}$ Iacob Mârza, Cultura şi îvățământul în secolul XVI-XVIII, în "Alba Iulia 2000", Alba Iulia, 1975, p. 196.

${ }^{47}$ Ioan Marin Mălinaş, Situația îvățământului bisericesc al românilor în contextul reformelor şcolare din timpul domniei împărătesei Maria Tereza (1740-1780), a împăraților Iosif al II-lea (1780-1790) şi Leopold al II-lea (1790-1792), Oradea, Editura „Mihai Eminescu”, 1994, p. 20.
} 
era pregătirea preoților, a cântăreților sau dascălilor. Cunoştințele ce trebuiau însuşite era: cititul, scrisul şi cântarea, iar de multe ori se cerea doar cititul şi cântarea, scrisul fiind: ,aproape numai privilegiul celor care doreau să devină copişti de manuscrise ${ }^{\text {,48; }}$ nici preoții nu ştiau toți să scrie. Copiştii cărților de cult erau preoți, călugări, cântăreți de biserică sau chiar simpli țărani. Cărțile de cult copiate şi cântările bisericeşti au menținut unitatea de credință a tradiției bizantine în Biserica Ortodoxă din Ardeal.

Cântările în slavoneşte erau cântate doar de cei care ştiau slavona, ceilalți (cei mulți) cântau în româneşte. Aceasta înseamnă că toate cărțile de cult muzicale (în sensul aplicării glasurilor) erau scrise în limba română dar cu litere sau caractere slavone (aşa numita scriere în potcoave), deci tălmăcite în româneşte dar cu alfabet slavon.

Mitropolia de la Alba Iulia, mai apoi Episcopia unită n-au fost văzute cu ochi buni de catolicii maghiari. Episcopul şi contele Ignaţiu Batyan a înaintat un raport, împăratului Iosif al II-lea prin care cerea ca aşa cum catolicii au stat în timpul reformaţilor cu un vicar, şi pentru români este suficient un vicar ${ }^{49}$.

În perioada imediată uniaţiei, românii treceau periodic şi în masă când la ortodocşi când la uniţi ${ }^{50}$. Practic nu se schimbase nimic, nici tradiția, nici slujba, nici cântarea, ei simpatizau cu omul, cu preotul. Ideea naţională, culturală şi muzicală din interior a însemnat pentru toți românii mai mult decât confesionalismul. Ortodocşii şi greco-catolicii au descoperit în ideea naţională şi în bogatele tradiţii culturale sursa fraternităţii ${ }^{51}$. Naţionalitatea şi cântarea străbună a bisericii, şi nu numai, îi făceau să-şi dea seama că au o singură credință şi că aceasta îi uneşte. În toiul marilor evenimente de la 1784 şi de la 1848 cântecele patriotice şi

\footnotetext{
${ }^{48}$ Ioan Lupaş,Istoria românilor ardeleni 1780-1792, Bucureşi, 1915, p. 15.

${ }^{49}$ Rolf Kutschera, Guvernatorii Transilvaniei (1691-1774), vol. X, Cluj, 1943, p. 66 .

${ }^{50}$ Keit Hitchins, Studii privind istoria modernă a Transilvaniei, Cluj-Napoca, Editura Dacia,1970, p. 68.

${ }^{51}$ Vasile Netea, Munţii Apuseni, Bucureşti, Editura Sport Turism, 1977, p. 128.
} 
religioase ale moților dădeau un puternic impuls spre afirmare culturală, spirituală şi naţională ${ }^{52}$. Prin cântările şi corurile organizate ulterior nu s-a făcut altceva decât să lumineze mintea şi să încurajeze sufletul românesc ${ }^{53}$, tot ce exista aici avându-şi „legenda şi cântecul” său ${ }^{54}$.

După organizarea învățământului ortodox exista o reală concurență între şcolile unite şi cele ortodoxe ${ }^{55}$. Se spune că şcolile lui Andrei Şaguna erau mai bine organizate, şi că el s-a opus înfiinţării de şcoli mixte (ortodoxe şi greco-catolice) ${ }^{56}$, şi chiar şi celor de stat pentru că ştia că limba germană sau maghiară se va impune în detrimentul limbii române ${ }^{57}$.

În şcolile ortodoxe, după ce s-au organizeazat, cântarea bisericii nu a fost uitată. Din contră ea este reluată şi perpetuată conform cerințelor vremii. La fel în şcolile Blajului, „Şcoala de Obşte", care a fost transformată în 1779 în Şcoala Normală, se învățau cântări religioase precum: Canonul Crucii, al Precestii, Preceasna, Cheruvicul şi Axionul ${ }^{58}$.

Că muzica psaltică era cunoscută de ardeleni reiese şi din faptul că la şcoala de psaltichie de pe lângă Biserica Colțea din București - înființată la începutul secolului XVIII - era un elev pe nume Ioanichie, de loc din Săscior (azi în județul Alba) care ajunge un mare învăţat mai târziu ${ }^{59}$. Acesta ca şi Gheorghe Ungureanu, probabil tot din zona Alba Iuliei, se întorc acasă aducând cu ei melosul bizantin învățat ${ }^{60}$. În şcolile Blajului, după

\footnotetext{
52 Ibidem, p. 148.

${ }^{53}$ Ibidem, p. 17.

${ }^{54}$ Keit Hitchins, op. cit., p. 4

${ }^{55}$ Ibidem, p. 46.

${ }^{56}$ Nicolae Albu, op.cit., p.174.

${ }^{57}$ Ibidem, p. 173.

${ }^{58}$ Ioan Mocean, Ioan Cenar, Alba Iulia - Monografie, Bucureşti, Editura SportTurism, 1980, p. 222.

${ }^{59}$ Gheorghe Lăncrănjan, Ion Truță, Învățământul până la 1848, în Alba Iulia 2000, op.cit., p. 247.

${ }^{60}$ Lucia Protopopescu, Contribuții la istoria învățământului din Transilvania, 1774-1805, Bucureşti, Editura Didactică şi Pedagogică, 1966, p. 249.
} 
uniaţie, s-a promovat şi cultivat muzica Bisericii Ortodoxe, căreia ulterior i s-a dat un caracter popular, dând naştere unei noi variante.

$\mathrm{Cu}$ mult mai devreme de secolul XIII ia ființă, lângă Alba Iulia, schitul „Sfântul Ioan Botezătorul”. În arhondaricul acestuia (în secolul XVI) a funcționat prima şcoală românească din actualul județ $^{61}$.

Sinodul de la 1675 ținut la Alba a hotărât ca fiecare preot să facă şcoală cu copiii, în biserică după slujbă ${ }^{62}$, şi să-i învețe scrisul, cititul şi cântarea.

Promovarea muzicii era şi în preocupările romanocatolicilor care, la 1560, înființează o şcoală de muzică condusă de un institutor francez şi care era de fapt şi întemeietorul ei. La Partoş, lângă Alba Iulia, exista o şcoală pe lângă biserica catolică de aici, construită în secolul XVII, unde copii învăţau să cânte la orgă. Azi această biserică nu mai există, pentru că s-a prăbuşit în timpul bombardamentelor din timpul primului război mondial.

Cât priveşte învățământul ortodox, putem spune că acesta a primit un imbold puternic datorită revoltei lui Horia, Cloşca şi Crişan. După înfrângerea mişcării, de frica alteia mai mari care mocnea în marea masă, apar şcolile ortodoxe. S-a pus chiar problema înființării unui seminar ortodox în Transilvania, probabil la Alba Iulia, fără însă să se fi realizat ${ }^{63}$. Educația muzicală din aceste şcoli nu poate fi pusă la îndoială. Dacă până acum se făcuse sporadic, acum se schimbă situația, odată cu organizarea învăţământului s-a trecut la folosirea ,noii sisteme” muzicale dimpreună cu cântările acesteia, care nu era alta decât vechea cântare folosită în bisericile ardelene. Se impune limba română, punându-se accent pe pregătirea preoților pentru că ei erau principalii piloni în societatea românească. Episcopii Sibiului: Nichitici şi Adamovici erau chiar speriaţi de slaba pregătire a

${ }^{61}$ Ioan Lupaş, Istoria bisericească a românilor ardeleni, Cluj-Napoca, 1995, p. 119.

${ }^{62}$ Romulus Felea, Țara Moților, IV, Cluj-Napoca, Editura “Atlas Clusium”, 1992, p. 190.

${ }^{63}$ Iacob Mârza, Şcoala şi națiune, Cluj-Napoca, Editura "Dacia”, 1987, p. 98. 
preoților. Au poruncit ca cei ce vor să fie preoți să ştie: ,,cetania, scrisoarea, cântarea, rânduiala bisericii şi catehismul" ${ }^{\prime 64}$.

Dacă vorbim de şcolile unite, trebuie să spunem că au avut un rol important în culturalizarea maselor populare româneşti, dar să nu uităm că Biserica Ortodoxă a fost crunt lovită, pentru că nefăcând "pactul cu Roma" nu avea posibilități materiale pentru şcoli şi îşi vedea adesea fiii duhovniceşti, dornici de cultură, trecând la greco-catolici. În şcolile unite se punea un mare accent pe muzică în sec XIX. Iacob Mureşianu, sufletul cântării de la Blaj, a muncit enorm până a creat făgaşul pe care să intre cântarea bisericească de aici. Aici, la Blaj, era studiată atât muzica vocală cât şi cea instrumentală, iar absolvenții şcolilor, fie laice, fie teologice, cunoşteau şi câte un instrument muzical ${ }^{65}$.

De la şcoala din tinda bisericii la cea sătească (sub oblăduirea Bisericii) şi până la cea de stat a fost un drum destul de lung. Durerea bisericii era de fapt a poporului.

Reformele iluministe a lui Iosif al II-lea au făcut în rândurile ortodocşilor şi victime, pe lângă unele privilegii (salarizarea dascălilor) ${ }^{66}$. Existenţa a două şcoli, una ortodoxă şi una grecocatolică îngreuna situația $^{67}$. Acum învățământul nu mai era o problemă, cântul bisericesc şi laic se putea învăța în libertate şi în baza unei tradiții. În trecut cântarea era obligatorie, căci în acest sens mitropolitul Dositei al Ardealului, la 4 iulie 1627, alcătuieşte un regulament al bisericii, în care între multe alte îndatoriri ale

\footnotetext{
${ }^{64}$ Dorin Giurgiu, Extrase Acta Musei Apulensis, Apulum XXXI, p. 369.

${ }^{65}$ Mihail Posluşnicu, Istoria muzicei la români, Bucureşti, Editura "Cartea Românească”, 1928, p. 109.

${ }^{66}$ Cornelia Papacostea-Danielopu, Lidia Demeny, Carte şi tipar în societatea românească şi sud-est europeană sec. XVII-XIX, Bucureşti, Editura Eminescu, 1985, p. 67.

${ }^{67}$ Cornelia Papacostea-Danielopu, Lidia Demeny, Carte şi tipar în societatea românească şi sud-est europeană sec. XVII-XIX, Bucureşti, Editura Eminescu, 1985, p. 67.
} 
preoților prevede ca ,, preotul ce nu va cânta liturghia să fie amendat cu 12 florini" ${ }^{68}$.

O îmbunătăţire substanţială a culturii româneşti s-a simțit în timpul principelui Gabriel Bethlem (1613-1629) ce întemeiază, în această perioadă, o şcoală românească în care să fie pregătiți preoții ortodocşi ${ }^{69}$. Înființarea acesteia se datora atât lui cât mai ales insistențelor conducătorului Mitropoliei, căci aşa cum fiecare episcop de la Bălgrad a marcat viața spirituală şi culturală ${ }^{70}$ tot aşa voia ca şi el să o sprijine.

Tot amarul vărsat de românii de pe melegurile Albei Iulii a fost răsplătit prin mărețul act de la 1 Decembrie 1918, iar apoi, prin primul liceu românesc din Ardeal înființat după Unire, în 1919, Liceul "Mihai Viteazul" (actualul liceu "Horia, Cloşca şi Crişan" $)^{71 .}$ La acest liceu a predat muzică, între anii 1919-1922, Nicolae Oancea, primul profesor de muzică al acestui liceu.

Cel mai important centru muzical din perioada Renaşterii este Alba Iulia, capitala Principatului Transilvănean. Aici principele Sigismund Bathory, mare iubitor de muzică, a adus muzicieni din Italia pe care i-a împroprietărit cu case şi cu pământ ${ }^{72 .}$ Un mare muzician şi organist, întemeietor şi conducător al şcolii de muzică de la Alba Iulia, era italianul Girolamo Diruta, a scris cunoscutul tratat de muzică „Transilvanio”, şi care a reuşit ca prin sprijinul lui Bathory să facă din Alba Iulia o mare metropolă muzicală renascentistă. Muzica organistică era utilizată atât la baluri, în piețe publice, cât şi în cadrul slujbelor religioase ${ }^{73}$. Numele adevărat a lui Diruta era Girolamo Mancini, nume primit

${ }^{68}$ Eva Mârza, Din istoria tiparului românesc. Tipografia de la Alba Iulia 15771702, Sibiu, Editura “Imago", 1998, p. 115.

${ }^{69}$ Ion Pleşa, Ioan Truță Valer Moga, Istoricul Colegiului Horia, Cloşca şi

Crişan, în Colegiul H.C.C. din Alba Iulia, 80 de ani de aniversare 1918-1999, Alba Iulia 1999, p. 18.

${ }^{70}$ Felician Roşca, Arta şi pedagogia organistică din România în context european, Timişoara, Editura Mirton, 2000, p. 47.

${ }^{71}$ Ibidem, p.48.

${ }^{72}$ Ibidem, p.51.

${ }^{73}$ Ibidem. 
odată cu intrarea lui în ordinul minoriților. Din muzica renascentistică, promovată şi cultivată de Girolamo şi Bathory, se dezvoltă în Transilvania muzica barocă. Renumitul organist, compozitor şi teoretician Girolamo Diruta s-a născut probabil în jurul anului 1550, şi-a început studiile muzicale în cadrul ordinului Sfântului Francisc de Assisi, iar când a ajuns la Alba Iulia, aici exista deja o orchestră şi o viață muzicală în plină ascensiune.

Sigismund Bathory, ca reprezentant al contrareformei în Transilvania, a aşezat în biserici orgile scoase de reformaţi şi dă muzicii importanța cuvenită, ea fiind sprijinită atât de principe cât şi de regina Izabella a Ungariei, descendentă din familia italiană (Sforza) ${ }^{74 .}$ Legăturile strânse dintre muzică şi aceştia se datorau şi faptului că erau foarte mulți italieni în gărzile din cetatea bălgrădeană. Tot ce era din Italia era foarte bine primit şi apreciat. Aşa se face că pentru o cât mai bună dezvoltare a muzicii va apare tratatul de muzică amintit, cu titlul generic de „Transilvano”. Pentru măiestria artei organistice, în 1613, Diruta este numit „Magister Musices”. Un tratat de măiestrie contrapunctică, în organistică, se păstrează în biblioteca Conservatorului din Paris şi care este atribuit lui Diruta ${ }^{75}$.Tratatul „Transilvano" cuprinde noțiuni de teorie muzicală, de teorie interpretativă şi exemple concrete de exerciții, de interpretare Importanța acestui tratat a făcut să fie împărțit în trei volume şi este valabil şi astăzi deşi a apărut în 1590, în urmă cu mai bine de 400 de ani.

Din secolul al XIII-lea orga însoțea în cadrul cultului soliştii sau corul, dădea amploare muzicii religioase cultice susținând vocile. Până în secolul al XIII-lea nu era admisă în bisericile romano-catolice din Transilvania.

Biserica Ortodoxă transilvăneană, în perioada Renaşterii şi Barocului folosea, în cadrul cultului, ca şi până atunci, cântarea bizantină. Credem că această muzică era cunoscută de autoritățile politice de atunci şi că uneori aceşti conducători participau la manifestările religioase ale ortodocşilor, pentru că erau majoritari

\footnotetext{
${ }^{74}$ Ibidem, p.52.

${ }^{75}$ Felician Roşca, op.cit.,p.72
} 
şi aveau nevoie de ei. Chiar dacă nu mergeau din convingere, mergeau din interes, iar dacă mai spuneau şi câteva cuvinte româneşti îi făceau pe români să fie oarecum mulțumiți.

Legăturile mitropoliților de la Alba Iulia cu celelalte două principate au făcut ca psalții să vină aici şi să încânte prin arta lor sufletele românilor. Bălgradul fiind un centru vestit din punct de vedere economic şi cultural, capitală a Transilvaniei, a făcut curioşi pe mulți călugări din țara Românească şi Moldova să cerceteze pe frații lor şi să le ducă ceea ce le era comun, cântarea.

Grecii, mari comercianți, erau sprijinitori ai muzicii psaltice în toate marile centre din Transilvania unde s-au stabilit. În Alba Iulia există o biserică numită „,Biserica grecilor” unde cu siguranță a fost practicată muzica bisericească psaltică. Chiar dacă mereu se fac afirmații de genul: „presupusa şcoală de pe lângă mitropolia Bălgradului" etc., argumentele logice vin să întărească existența acesteia prin populația majoritar ortodoxă, existența unei mitropolii ortodoxe, dăinuirea de secole întregi a bisericii ortodoxe sub dominație străină (politică şi religioasă), existența a numeroase biserici, schituri şi mănăstiri ortodoxe, etc. Toate acestea ne arată că în Alba Iulia Biserica Ortodoxă a avut o şcoală unde era învățată muzica bisericească psaltică şi tot ceea ce ține de biserică şi cult.

\section{Concluzii}

Astăzi în oraşul Alba Iulia există coruri aproape în toate bisericile precum şi în parohiile mai mari din această eparhie. Un cor renumit în oraşul Alba Iulia era cel de la Biserica "Bunavestire" numită şi "Biserica grecilor", care a fost construită de protopopul Nicolae Rațiu, duhovnicul martirilor Horea, Cloşca şi Crişan. Importanța istorică a acestei biserici l-a determinat pe Nicolae Iorga să o viziteze. Tot aici au activat la sfârşitul secolului XIX şi începutul secolului XX cântăreți renumiți ca: Ioan Perian şi Grigor Baba. Corul Bisericii centrale sau corul Bisericii „Bunavestire” se numea, de fapt, „Asociaţia corală Bunavestire” şi a dat numeroase concerte pentru strângeri de ajutoare în scopuri 
umanitare. La pupitrul acestui cor a ajuns compozitorul şi muzicologul Ion Cunțan, după ce instruise un foarte bun cor în oraşul Sebeş de lângă Alba Iulia.

Discuții şi păreri vis-a-vis de cântările bisericeşti din Ardeal au fost şi există. Mihail Posluşnicu vorbeşte în Istoria muzicii la români, de un oarecare Ioan Bota, învăţător în Sălciua de Sus (eparhia Alba), lângă Lupşa, că a dat Academiei Române la 25 mai 1885, o carte de „Cântări bisericeşti, care datează de prin secolul XVIII şi care cuprinde: Triod, Penticostar, Minei, începând de la duminica Vameşului şi Fariseului, până la duminica Tuturor Sfinţilor, Tropar la Vinerea a VI-a din Post şi la Sâmbăta lui Lazăr, Tropar la Duminica Floriilor" Informaţia este neclară; cartea nu este găsită nicăieri.

La Alba Iulia în secolul XVII, Mitropolitul Simion Ştefan (1643-1656) publică „Cântările noastre bisericeşti deosebite de cele latineşti”. Aceasta a fost scrisă probabil ca răspuns la cântecele bisericeşti calvine ale lui Mihail Tordaşi, care circulau şi se impuneau credincioşilor ortodocşi pentru a le învăţa. 